\title{
An Empirical Test of the Inequality Trap Concept
}

\author{
Caroline Daymon* \\ Celine Gimet
}

\begin{abstract}
The new concept of inequality trap, has recently appeared in the economic development literature. This phenomenon is due to the persistence of the poor initial conditions, in the presence of both market and institutional imperfections. The aim of this paper is to test the validity of this concept. The Generalized Method of Moments estimation is used to study the inequalities reproduction and the lagged impact of gender, political and economic liberties on inequality. The results proves the existence of such traps and underline the significant influence of the credit market, wealth and education access initial levels over a generation.
\end{abstract}

\footnotetext{
*enter of International Economics and Finance, Faculty of Economics and Management, University of the Mediterranean, Chateau Lafarges, route des Milles, 13290 Aix-en-Provence, France. Tel: 0033442935993. Fax: 0033442389585 .

Email: carolinedaymon@ @otmail.com (corresponding author), celinegimet@free.fr

We are grateful to Pr James K. Galbraith for providing us the UTIP-UNIDO database, and to Charles Laï Tong for his precious help.
} 


\section{The Ineqality Trap Concept}

The World Development Report (WDR) points out the existence of a circular causal relation between wealth, income, sociocultural capital and power (Roa, 2006). Power inequality results in a political system in which everybody's preferences are not equally represented, but in which, on the contrary, leaders favour the interests of the group to which they belong. In this case, institutions contribute to the persistence of initial conditions and to the setting up of real inequality traps. As well as the question of the intergenerational persistence of lifetime earnings ${ }^{1}$, the notion of inequality traps refers to the transmission of economic inequalities, but it also covers political, social and cultural inequalities. One of the key issues related to the matter of inequality traps is how to distinguish this concept from that of the poverty trap (Azariadis and Stachurski, 2004). The nuance between the two notions depends on the way in which the different groups of society interact. Thus, when we talk of poverty traps we are referring to the lack of opportunities available to the poor and implying that there is both chronic and transient poverty ${ }^{2}$. On the other hand, in the case of inequality traps this lack of opportunities is accompanied by stagnation in the society's income distribution structure. Poverty is then chronic, as mobility within the distribution is blocked. In this case, even if opportunities for the poor increase, the non-egalitarian nature of the economic, social and polical environment is such that the comparative advantage is always in favour of the rich and leads to durable inequality (Tilly, 1998). The two trap phenomena have thus different determinants which require the setting up of specific policies. This study will be specifically devoted to determining those concerning inequality traps.

This article's main contribution is to empirically test the existence of such a phenomenon on a global level, by highlighting the conditions which favour intergroup reproduction of inequality. To do this we have chosen an econometric application based on a system GMM estimator. The other original aspect is that, for this purpose, we use the EHII index taken from the Galbraith and Kum database which we have extended to 2003. First, we present the method and the variables used, whilst the third section is devoted to a study of the results.

\footnotetext{
${ }_{1}^{1}$ For a review of empirical literature on the subject see Mulligan (1997) and Solon (1999).

2 Jalan and Ravallion (2001) or again Baulch and McCulloch (2000) divide poverty into a persistant or chronic element and another transient or temporary one.
} 


\section{The Empirical Study}

When we talk of inequality traps, this implies the persistence over time of inequality of opportunity and of the relative positions in distribution. What is important in the transmission of advantages is therefore both the initial position of an individual and that of distribution in general $^{3}$. However, with the exception of Brasil, there is not enough temporal data on the subject in emerging countries to enable us to study individuals' mobility within income distribution according to their initial opportunies (the elasticity of the child's income with respect to the parents' income... ). This statistical constraint prevents us from proving the existence of inequality traps within the different countries by comparing the present day distribution and an expected situation (as advised by Bourguigon et al., 2006). In order to solve this problem, this study is going to concentrate on comparing the inequality dynamics in countries facing very different initial conditions in terms of opportunity distribution. Thus, if the results show that inequality in these countries is closely correlated to the initial conditions and that they are really being reproduced, we are facing worldwide reproduction of intergroup inequalities.

\subsection{The GMM Model}

As the study of inequality traps refers to a dynamic process, we must study to what extent the lagged values of the inequality indicators and the initial political and sociocultural conditions influence the current value of income distribution. The starting point for this analysis is a simple regression using the endogenous lagged variable as well as the explanatory variables for the t-1 period. When the ordinary least squares estimator is used for this purpose, there is a problem of correlation between the explanatory variables and the error term due to individual effects, which then gives this an upward bias. The within estimator enables us to eliminates this problem by integrating fixed effects in the aim of taking into account national specificities. Nevertheless, in the context of our analysis, there is a limited number of periods and this produces a significant correlation between the dependent lagged variable and the error term. Therefore, the use of this estimator is also biased, but in the opposite direction. Given the problems encountered by these two methods, it is advisable to use a dynamic model allowing the introduction of instrumental variables. These variables are correlated to the lagged value of the endogenous variable and not with the error term of the model (for $t=2$,

\footnotetext{
${ }^{3}$ For a study of intergenerational income elasticity applied to the United States see Mazumder (2005).
} 
$3, \ldots, \mathrm{T})$, which solves our problem. The effects of the explanatory exogenous variables on the explained variable can then be interpreted (Bond, 2002). The GMM therefore seems the method best adapted to our estimation. It should be noted that Blondel and Bond's (1998) Monte Carlo simulations showed that the system GMM estimator is more efficient than the first-differenced one. Indeed when the number of instruments is small and when there is a finite sample, the first-differenced GMM estimator is biased.

It should also be noted that in order to validate the use of a GMM model, the estimated coefficient of the dependent lagged variable must be larger than that of the within estimator and smaller than that of the OLS estimator. Our model can be written as follows:

$$
y_{i, t}=\alpha y_{i, t-1}+\beta X_{i, t-1}+u_{i}+v_{i, t}
$$

With $\mathrm{i}=1, \ldots, 71$, and $\mathrm{t}=2, \ldots, 7$ or $\mathrm{t}=2, \ldots, 4$.

Where $y_{i, t-1}$ represents the dependent lagged variable for each country in the period $\mathrm{t}-1, X_{i, t}$ the set of explanatory lagged variables, $u_{i}$ the specific individual effect for each country, $v_{i, t}$ the specific shock at each period and on each country.

Where $\left.E \mid x_{i, t}\left(u_{i}+v_{i, t}\right)\right]=0$ for $\mathrm{i}=1, \ldots, 71$, and $\mathrm{t}=2, \ldots, 7$ or $\mathrm{t}=2, \ldots, 4$.

\subsection{Justification of the Choice of Variables}

Criticism of the different databases on inequality concern in particular the infrequency of data which leads most studies to content themselves with extrapolating the Gini values between two surveys (Ravallion, 2001; Lopez, 2003). Moreover, their low quality can lead to doubt with regard to the reliability of the results obtained, which poses a problem when we want to make comparisons between two countries. In order to improve the quality of work on inequalities, it is therefore necessary to be able to carry out modelling with weaker asumptions about the variables, especially to avoid serial dependencies in measurement errors.

Galbraith and Kum (2003) found a solution to these difficulties by suggesting a new inequality estimator called EHII (Estimation of the Household Inequality and Inequity). The advantage of this indicator is that it covers a large number of countries over a longer period 
than Deininger and Squire's (1996) database ${ }^{4}$. This EHII indicator is based on the measurement of salary dispersion in different industrial categories of the manufacturing sector. Galbraith and Kum (2005) justify associating the concepts of payment and income inequality by the fact that in the majority of emerging countries the main source of income comes from wages and, principally, from manufacturing wages. Moreover, they consider that inequality variations within the manufacturing sector represent, to a certain extent, inequality variations in the overall wage structure, unqualified workers with low wages having the same profile in the different sectors of activity. The EHII indicator is calculated taking into account wage inequalities (UTIP-UNIDO) ${ }^{5}$, the share of manufacturing employment in the total population, as well as three dummy variables devised from Deininger and Squire's dataset (1996). According to Galbraith and Kum's studies (2005), the dummy variables (G, H, I) take respectively the value 0 or 1 for each country depending on whether the calculation of Deininger and Squire's inequality indicator is based on gross or net income, on whether the calculation is based on household or individual income and on whether the calculation was based on income or expenditure. The database proposed goes from 1963 to 1999, so we have extended the analysis period by determining EHII values up until 2003 thanks to the UTIPUNIDO data supplied by James K. Galbraith.

The dependent variable used to prove the existence of inequality traps on an international level will therefore be the EHII variable. The use of this variable enables us to have a broader representation of emerging countries in our database than in the majority of studies. In fact, in this article, out of 71 countries studied from 1965 to 2000, 31 are developed countries, 25 of which are members of the OCDE, and 40 are emerging countries. ${ }^{6}$

The interest of taking the ehii variable one period lagged (ehiit-1), is to incorporate a dynamic aspect in the model to show the persistence of inequalities over time. Moreover, as the tests were based on databases over 5 and 10 years, this gives a new perspective to the analysis. This variable thus enables us to evaluate all aspects of inequality traps. The other explanatory variables chosen ${ }^{7}$ represent economic, political and social inequalities. The sign given in brackets is that of the anticipated relation between the degree of inequality and each of the explanatory variables. Most of the data comes from the World Development Indicators (World Bank, 2005a).

\footnotetext{
${ }^{4}$ For a more detailed comparison of these two databases, refer to World Bank (2002) and Galbraith and Kum (2003).

5 UTIP-UNIDO: University of Texas Inequality Project and United Nations Industrial Development Organization.

${ }^{6}$ According to the World Bank's classification of countries: World Bank List of economies (July 2006).

${ }^{7}$ No collinearity bias exists between these variables as is shown in Annexe 1.
} 


\section{Economic and political inequalities}

For Cling et al. (2005) the emergence of an inequality trap can to a great extent be explained by political power inequality which leads to the establishment of inequitable institutions and helps to maintain the inequality situation within the country. In effect, these institutions do not try to promote policies aimed at assisting the most destitute. On the contrary, an unequal distribution of power between the rich and the poor helps the elite keep control of resources. The poor are therefore not in a position to break this circle of poverty (illiteracy, malnutrition ...). Moreover, the lack of protection discourages investment particularly as the credit market offers them no possibilites, and this helps to perpetuate inequality. The assumption made here is that efficient markets and institutions guaranteeing equity are the necessary conditions for combatting inequality traps.

- Political liberty $(p r)$ : rating of political rights from 1 to 7 , with 1 representing the best mark and 7 representing the lowest degree of freedom. (Freedom House) (+). The rating is based on the reliabilty of the electoral process, the people's participation in political life, the self-determination of cultural, ethnic or religious minorities, the government's corruption and the amount of transparency in its running of the country.

- Credit access (domcred): relation between domestic credit and the gross domestic product (-). This variable shows to what extent the country calls on the banking system in order to finance its economy (International Financial Statistics, Internation Monetary Fund).

\section{Social and cultural inequalities}

With regard to social and cultural inequalities, the WDR 2006 stresses the domination relations linked to literacy, gender and ethnic identity which influence the capacity of certain groups to integrate the growth process. Social stratification is such that underprivileged populations incorporate this social reproduction in their decisions, which gives rise to a lower "aspiration capacity", , to such an extent that it acts as a self-fulfilling prophecy.

- Women's access to education (literatyfm): share of literate women compared to literate men between the ages of 15 and 24 (goal 3 of the MDG) ${ }^{9}(-)$. This variable

\footnotetext{
${ }^{8}$ Rao, 2006.

${ }^{9}$ MDG: Millenium development goals.
} 
refers to the notion of inequality traps for women. Thus, the discrimination suffered by women reduces their education, their professional and social integration, their decision power. This task discrimination based on sex causes a gender inequality which is passed on the the next generation (Roa, 2006).

- Youth literacy rate (literacyyoung): share of young people between 15 and 24 likely to be able to read, write and understand a short, simple text about everyday life (-). This indicator reveals the proportion of children who have had access to the primary education system which enabled them to acquire the basic skills necessary for upward mobility and the development of an entrepreneurial spirit. As the WDR 2005 stresses, promoting equity in the field of human abilities inevitably involves paying particular attention to very young children.

- Population growth (popgrowth): annual exponential change in the population actually present for a given period in a given country (+). The Sarkar model (2005) underlines the role played by population growth in the persistence of inequalities. Indeed, it would appear that when families choose to have many children this reduces savings (Sachs, 2005) and investment in education (de la Croix and Doepke, 2002), from then on the fertility differential between rich and poor (Ahluwalia, 1976) would seem to tend to increase inequalities ${ }^{10}$.

- Infantile mortality (mortalityyoung): probability of a child dying before the age of 5 for 1000 children (Goal 4 of the MDG) (+). According to Deaton (2003) and Lynch et al.'s (2004) studies, the literature comes to the conclusion that there is a strong correlation between inequality and mortality. It is therefore interesting to ask oneself to what extent infantile mortality affects inequality traps.

\footnotetext{
${ }^{10}$ We have used population growth as a proxy for demographic transition, for there is no unanimously recognised indicator (controversy over Coale's indexes) and there is the problem of the infrequency of samples for creating them.
} 


\section{The Results}

Table 1. Results of the OLS, WITHIN and GMM analyses over a period of 5 years

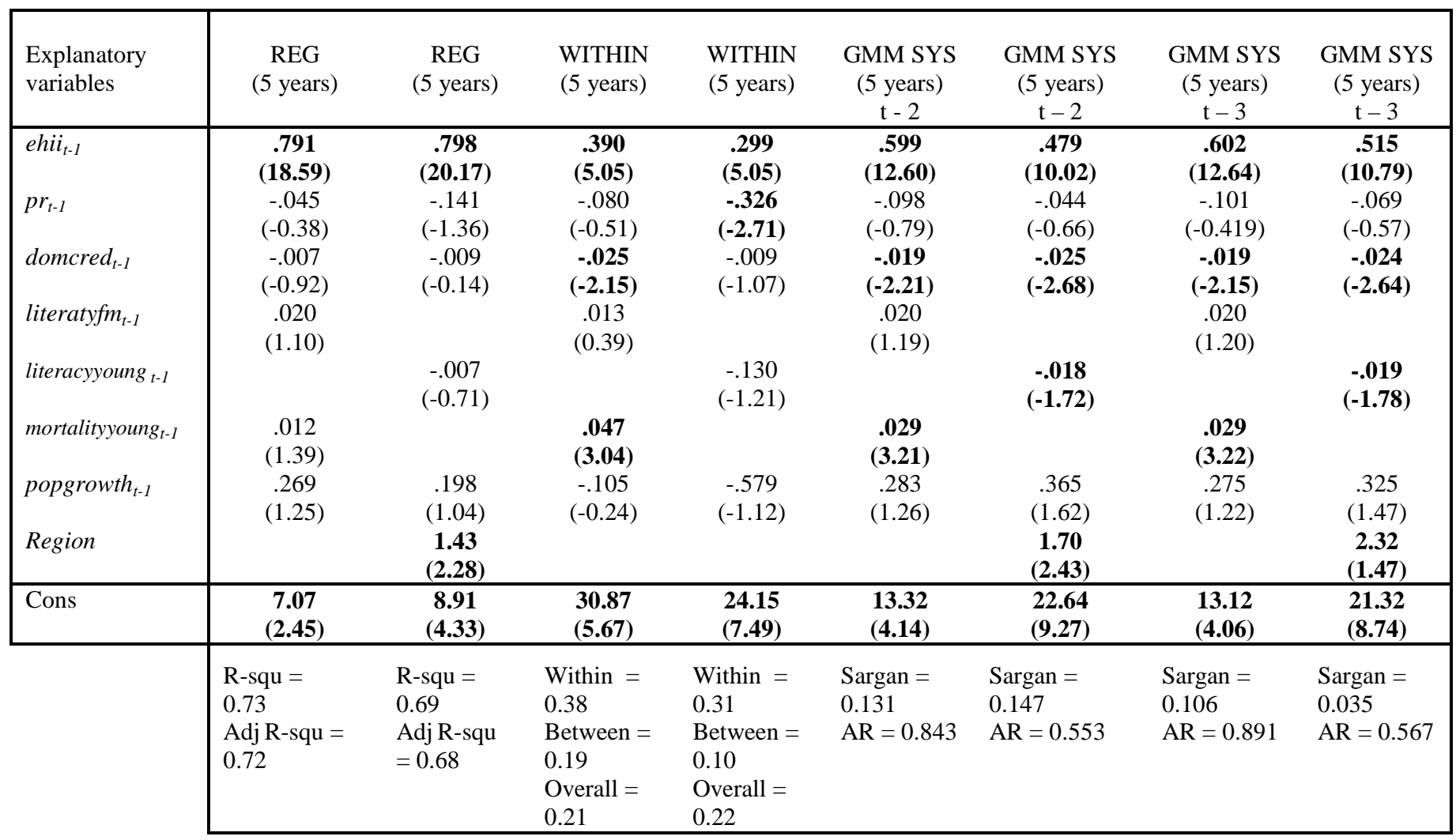

Table 2. Results of the OLS, WITHIN and GMM studies over a period of 10 years

\begin{tabular}{|c|c|c|c|c|c|c|c|c|}
\hline $\begin{array}{l}\text { Explanatory } \\
\text { variables }\end{array}$ & $\begin{array}{c}\text { REG } \\
\text { (10 years) }\end{array}$ & $\begin{array}{c}\text { REG } \\
\text { (10 years) }\end{array}$ & $\begin{array}{l}\text { WITHIN } \\
\text { (10 years) }\end{array}$ & $\begin{array}{l}\text { WITHIN } \\
\text { (10 years) }\end{array}$ & $\begin{array}{c}\text { GMM SYS } \\
(10 \text { years }) \\
t-2\end{array}$ & $\begin{array}{c}\text { GMM SYS } \\
\text { (10 years) } \\
t-2\end{array}$ & $\begin{array}{c}\text { GMM SYS } \\
\text { (10 years) } \\
t-3\end{array}$ & $\begin{array}{c}\text { GMM SYS } \\
\text { (10 years) } \\
t-3\end{array}$ \\
\hline ehii $t_{t-1}$ & $\begin{array}{l}.773 \\
(11.81)\end{array}$ & $\begin{array}{c}.760 \\
(11.04)\end{array}$ & $\begin{array}{c}.115 \\
(1.65)\end{array}$ & $\begin{array}{c}.089 \\
(0.402)\end{array}$ & $\begin{array}{c}.499 \\
(7.70)\end{array}$ & $\begin{array}{c}.481 \\
(6.67)\end{array}$ & $\begin{array}{c}.530 \\
(8.18)\end{array}$ & $\begin{array}{c}.511 \\
(7.23)\end{array}$ \\
\hline$p r_{t-1}$ & .082 & .025 & .020 & .165 & .037 & .091 & .082 & .122 \\
\hline & $(0.46)$ & $(0.15)$ & $(0.10)$ & $(0.79)$ & $(0.20)$ & (0.49) & $(0.65)$ & $(0.67)$ \\
\hline domcred $_{t-1}$ & $\begin{array}{c}-.003 \\
(-0.30)\end{array}$ & $\begin{array}{c}-.005 \\
(-0.48)\end{array}$ & $\begin{array}{l}-.016 \\
(-1.15)\end{array}$ & $\begin{array}{l}-.006 \\
(-0.41)\end{array}$ & $\begin{array}{c}-.037 \\
(-2.88)\end{array}$ & $\begin{array}{c}-.036 \\
(-2.54)\end{array}$ & $\begin{array}{l}-.038 \\
(-2.95)\end{array}$ & $\begin{array}{c}-.036 \\
(-2.57)\end{array}$ \\
\hline literatyfm $_{t-1}$ & $\begin{array}{c}.003 \\
(0.16)\end{array}$ & & $\begin{array}{c}.026 \\
(0.68)\end{array}$ & & $\begin{array}{c}.019 \\
(0.82)\end{array}$ & & $\begin{array}{l}-.013 \\
(-0.59)\end{array}$ & \\
\hline literacyyoung $_{t-1}$ & & $\begin{array}{l}-.010 \\
(-0.70)\end{array}$ & & $\begin{array}{l}-.200 \\
(-0.97)\end{array}$ & & $\begin{array}{c}-.019 \\
(-1.37)\end{array}$ & & $\begin{array}{l}-.017 \\
(-1.23)\end{array}$ \\
\hline mortalityyoung $_{t}$ & $\begin{array}{l}.006 \\
(0.49)\end{array}$ & & $\begin{array}{c}.067 \\
(4.28)\end{array}$ & & $\begin{array}{c}.026 \\
(2.05)\end{array}$ & & $\begin{array}{c}.021 \\
(1.65)\end{array}$ & \\
\hline $\begin{array}{l}\text { popgrowth }_{t-1} \\
\text { Region }\end{array}$ & $\begin{array}{l}.274 \\
(1.00)\end{array}$ & $\begin{array}{c}.195 \\
(0.72) \\
\mathbf{1 . 8 1} \\
(\mathbf{1 . 8 5}) \\
\end{array}$ & $\begin{array}{c}.012 \\
(0.03)\end{array}$ & $\begin{array}{l}.195 \\
(0.44)\end{array}$ & $\begin{array}{l}.506 \\
(1.89)\end{array}$ & $\begin{array}{c}.391 \\
(1.42) \\
1.23 \\
(1.26) \\
\end{array}$ & $\begin{array}{l}.481 \\
(1.81)\end{array}$ & $\begin{array}{c}.382 \\
(1.40) \\
1.05 \\
(1.09) \\
\end{array}$ \\
\hline \multirow[t]{2}{*}{ Cons } & $\begin{array}{c}9.29 \\
(2.34) \\
\end{array}$ & \begin{tabular}{|c|}
9.86 \\
$(2.99)$ \\
\end{tabular} & \begin{tabular}{|l|}
$\mathbf{4 3 . 0 1}$ \\
$(\mathbf{7 . 0 3})$ \\
\end{tabular} & \begin{tabular}{|l|}
26.95 \\
$(4.71)$ \\
\end{tabular} & \begin{tabular}{|l|}
22.18 \\
$(5.49)$ \\
\end{tabular} & $\begin{array}{l}22.29 \\
(6.57) \\
\end{array}$ & $\begin{array}{l}21.44 \\
(5.34) \\
\end{array}$ & $\begin{array}{l}20.77 \\
(\mathbf{6 . 1 2}) \\
\end{array}$ \\
\hline & $\begin{array}{l}R-s q u=0.60 \\
\text { Adj R-squ }= \\
0.58\end{array}$ & $\begin{array}{l}\text { R-squ = } \\
0.61 \\
\text { Adj R-squ } \\
=0.59\end{array}$ & $\begin{array}{l}\text { Within = } \\
0.34 \\
\text { Between = } \\
0.11 \\
\text { Overall = } \\
0.02\end{array}$ & $\begin{array}{l}\text { Within = } \\
0.29 \\
\text { Between = } \\
0.09 \\
\text { Overall = } \\
0.03\end{array}$ & $\begin{array}{l}\text { Sargan }= \\
0.002 \\
\text { AR }=0.001\end{array}$ & $\begin{array}{l}\text { Sargan }= \\
0.001 \\
A R=0.001\end{array}$ & $\begin{array}{l}\text { Sargan = } \\
0.704 \\
\text { AR }=0.001\end{array}$ & $\begin{array}{l}\text { Sargan = } \\
0.723 \\
\text { AR }=0.001\end{array}$ \\
\hline
\end{tabular}


If the study proves the existence of inequality traps on an international level, it appears that this phenomenon is all the more marked in emerging regions as the dummy variable ${ }^{11}$ (region) shows. Indeed, the dependent lagged variable over 5 and 10 years has a significant impact on distribution whatever methodology is chosen. As the aim is to show the dynamic aspect of inequality, it is interesting to concentrate in particular on the results provided by the GMM estimation. We can see here that the use of the dynamic panel model is validated, because the coefficient of this GMM estimated variable is higher than that of the within estimator and lower than that of the OLS estimator. In the context of the study made over a 5 year period, when we consider the t-2 period the model is overidentified, that is to say the number of instruments is larger than the number of endogenous variables. In this case, the Sargan test validates the use of lagged variables as instruments ( $p=0.131$ and 0.147$)$. Indeed, the assumption according to which the instrumental variables are not correlated to the error terms is not rejected. Besides, the Arellano and Bond test does not allow us to reject the assumption of second order autocorrelation $(p=0.843$ and 0.553$)$. This study therefore enables us to make a correct interpretation of the estimation's results. Likewise, the Sargan test is correct in the t-3 analysis over periods of 5 and 10 years. On the other hand, the analysis over a period of 10 years does not pass the Arellano and Bond test $(p=0.001$ and $0.001)$.

The variables related to gender discrimination concerning access to education and infant mortality are not studied jointly with the variable related to child literacy because of a redundancy of information which could lead to a collinearity bias in the analyses (Apendix 1).

These results underline the influence of initial conditions with regard to economic inequalities, access to health and fertility. Thus, the first category of indicators enables us to conclude that inequality traps depend on the economic environment. The negative impact of the domcred indicator shows that low access to financial resources for the most destitute tends to foster the inequality phenomenon. As an individual's loan capacity is linked both to its earnings and to its initial provision of wealth, the investment ambitions of the neediest cannot therefore be fulfilled. So we note an endless reproduction of these situations and the persistence of inequalities. On the other hand, if there are no power relations which lead to the exclusion of a part of the population from the credit market, the poor will be able to become

\footnotetext{
${ }^{11}$ Carrying out GMM regressions specific to the 40 emerging countries does not enable us to obtain sufficiently reliable results because of the shortage of the sample. We therefore decided to introduce a dummy variable to seperate industrialised countries from developing countries. In the case of within regressions, the introduction of the dummy variable to distinguish the countries' profile is not desirable as the countries' specificity has already been taken into account by the introduction of fixed effects.
} 
entrepreneurs or send their children to school (Ray, 1998; Ferreira and Walton 2005). Besides, the $p r$ variable is only significant in the case of a within regression, which does not allow us to draw a conclusion concerning the direct influence of the institutional environment on inequality traps. We can therefore suppose that institutions have a positive but indirect effect on the correction of market imperfections by improving the legal system (ownership rights ...).

In order to put an end to inequality traps and reach an equitable development ${ }^{12}$, the second category of variables shows that it is necessary not to neglect the elimination of absolute deprivation. The analysis underlines in particular the significant impact of the access of the most destitute populations to basic needs, notably with regards to health, on inequality reproduction (mortalityyoung). It would seem therefore that access to health is a sine qua non condition for beginning an equalisation process of the opportunities offered to different groups ${ }^{13}$. The same is true in the matter of demographic transition as results show that population growth (popgrowth) tends to foster inequalities. This phenomenon only acts on the long term (10 year periods), which underlines the reproduction of social stratification from one generation to another. It therefore appears that the which have not acheived there demographic transition suffer from a handicap with regard to access to the opportunities necessary for breaking the vicious circle of inequalities. On the other hand, if the non significance of the literatyfm variable does not allow us to judge the size of gender inequality traps, we can nevertheless assume this has an indirect impact on population growth. Indeed, if girls have access to education, this supposes they begin their working lives later. The negative impact of this on the fertility rate indicates then a decrease in inequalities and better opportunities offered to future generations. It should be noted that what is important in this variable is not access to education but, specifically, discrimination based on sex. Indeed, when we study more particularly the elimination of illiteracy among very young children (literacyyoung $t-1$ ), this variable plays an important part in inequality reproduction. Unless efficient education policies are set up, children from the poorest backgrounds have thus little chance of benefiting from upward social mobility.

\footnotetext{
${ }^{12}$ The notion of equitable development is defined and defended by Bourguignon et al (2006), Ferreira and Walton (2005) and the WDR 2006 (p.11).

${ }^{13}$ This approach is in the tradition of the work of Rawls, Dworkin, Sen and Roemer (Ferreira, Walton, 2005).
} 


\section{Conclusion}

In this article we have shown the existence of inequality traps on a global level. The use of a panel data estimation has enabled us to stress the dynamics of inequalites. The use of the EHII indicator has also given us the possibility of working on a large sample of countries between 1965 and 2000. Our results empirically validate the assumptions made by Feirrara and Walton (2005), and confirm that the economic and sociocultural environment has a significant influence on inequality traps.

Moreover, it seems that the political context has only an indirect impact on inequalities by improving market functioning. Likewise, in the case of gender inequality decreases, we suppose that the beneficial effect on inequality traps can be seen in particular in population growth.

Our study therefore allows us to define the priority which must be given to access to health, education and financial resources in order to improve the opportunities offered to the neediest and thus put a stop to inequality reproduction. For these measures to be effective, it is preferable for the countries to have achieved (or begun) their demographic transition. We must nevertheless be vigilant because the impact of these recommendations will vary according to the countries studied.

Moreover, it appears that the inequality trap problem is connected to another broader question, that of inequality determinants. It therefore seems necessary to complete this analysis by undertaking more detailed studies into inequality determinants on a regional level, in order to study the revelance of regional politics to the inequality and equity question. For example, in the MENA countries reduction of gender discrimination plays an important part in the decrease of inequality (Daymon and Gimet, 2007). Moreover, as Bourguignon et al. advise (2006), it would be interesting to apply the inequality traps concept to international reports. The circular relationship between political inequalities, economic inequalities and sociocultural inequalities could also provide a relevant analysis grid for implementing equitable development policies. 


\section{Appendix}

\section{Table 3. Correlation Test of Explicative Variables}

\begin{tabular}{l|lllllll} 
& ehii & pr & domcred & literatyfm & literatyyoung & mortalityyoung & popgrowth \\
\hline ehii & 1.0000 & & & & & & \\
pr & 0.1953 & 1.0000 & & & & & \\
domcred & -0.4627 & -0.2711 & 1.0000 & & & & \\
literatyfm & -0.1912 & -0.5272 & 0.3169 & 1.0000 & & & \\
literatyyoung & -0.2202 & -0.3744 & 0.3502 & 0.8903 & 1.0000 & \\
mortalityyoung & 0.3129 & 0.4904 & -0.4951 & -0.7289 & -0.7920 & 1.0000 & 1.0000 \\
popgrowth & 0.3170 & 0.4803 & -0.3263 & -0.5013 & -0.4581 & 0.5020 &
\end{tabular}

\section{References}

Ahluwalia, M.S. (1976) Inequality, Poverty and Development. Journal of Development Economics, 3, pp. 307342.

Azariadis, C. and Stachurski, J. (2004) Poverty Traps, in Aghion P. and Durlauf S. (eds) Handbook of Economic Growth, (Elsevier, Amsterdam).

Baulch, B. and McCulloch N. (2000) Simulating the Impact of Policy upon Chronic and Transitory Poverty in Rural Pakistan. Journal of Development Studies, 36(6), pp. 100-130.

Blundell, R. and Bond S.R. (1998) Initial conditions and moment restrictions in dynamic panel data models. Journal of Econometrics, 87, pp. 115-143.

Bond, S.R. (2002) Dynamic panel data models: a guide to micro data methods and practice. Portuguese Economic Journal, (1), pp. 141-162.

Bourguignon, F., Ferreira, F.H.G., and Walton, M. (2007) Equity, Efficient and Inequality Traps: A Research Agenda. Journal of Economic Inequality, 5(2), pp. 235-256.

Cling, J.P., Cogneau, D., Loup, J., Naudet, J.D., Razafindrakoto M., and Roubaud, F. (2005) Le développement, une question de chances: A propos du rapport sur le développement dans le monde 2006 Equité et Développement. Working Paper DIAL, No. DT/2005(15).

Coale, A. J. (1973) The demographic transition. IUSSP Liege International Population Conference, 1, pp. 53-72.

Daymon, C., and Gimet C. (2007) Les déterminants de l'inégalité et le rôle de l'équité dans les pays du MoyenOrient et de l'Afrique du Nord. Région et Développement, 25.

Deaton, A. (2003) Health, inequality, and economic development. Journal of Economic Literature, (41), pp. 113-158.

De la Croix, D., and Doepke, M. (2002) Inequality and Growth: Why Differential Fertility Matters. UCLA Economics Working Papers, No. 803, UCLA Department of Economics.

Deininger, K., and Squire, L. (1996) A New Data Set Measuring Income Inequality. World Bank Economic Review, (10), pp. 565-591.

Ferreira, F.H.G., and Walton, M. (2005) The Inequality Trap: Why equity must be central to development policy. Finance \& Development, 42(4), pp. 34-38.

Freedom House. The Freedom in the World survey. 2005.

Galbraith, J. K., and Kum, H. (2003) Inequality and Economic Growth. A Global View Based on Measures of Pay. CESifo Economic Studies, 49(4), pp. 527-556. 
Galbraith, J. K., and Kum, H. (2005) Estimating the Inequality of Household Incomes: A Statistical Approach to the Creation of a Dense and Consistent Global Data Set. Review of Income and Wealth, 51(1), pp. 115-143.

Heerink, N. (1994) Population Growth, Income Distribution and Economic Development. International Journal of Forecasting, 11(2), pp. 333-334.

Jalan,, J., and Ravallion, M. (2001) Household Income Dynamics in Rural China. World Bank Policy Research Working Paper No. 2706.

Lynch, J., Smith, G.D., Harper, S., Hillemeier, M., Ross, N., Kaplan, G.A., and Wolfson, M. (2004) Is income inequality a determinant of population health? Part 1, A systematic review. Milbank Quarterly, 82 (1), pp. 5-99.

Lopez, H. (2003) Macroeconomics and Inequality. Research workshop macroeconomic challenges in low income countries, October 23-24, 2003.

Mazumder, B. (2005) The Apple Falls Even closer to the Tree than We Thought: New and Revised Estimates of the Intergenerational Inheritance of Earnings. ( S. Bowles, H. Gintis, and M. Osborne Groves).

Mulligan, C.B., (1997) Parental Priorities. (University of Chicago Press, Chicago).

Rao, V., (2006) On 'Inequality Traps’ and Development Policy. World Bank: Development Outreach, February, pp. 10-13.

Ravallion, M., (2001) Inequality Convergence. World Bank Policy Research Working Paper No. 2645.

Ray, D., (1998) Development Economics (Princeton University Press, Princeton NJ).

Sachs, J. D., (2005) The End of Poverty: Economic Possibilities for Our Time (Penguin Press, New York).

Sage, C., and Woolcock, M. (2005) Breaking legal inequality traps: new approaches to building justice systems for the poor in developing countries. Arusha Conference, "New Frontiers of Social Policy”, December 1215,2005

Sarkar, J., (2005) Mortality, Fertility and Persistent Income Inequality. $75^{\text {th }}$ Southern Economic Association Conference, Washington D.C., 2005.

Solon, G., (1999) Intergenerational mobility in the labor market (Ashenfelter, O., and R. Layard), Handbook of Labor Economics, vol. 3C. Elsevier, Amsterdam.

Tilly, C., (1998) Durable Inequality. (University of California Press, Berkeley, CA).

United Nations International Development Organization (UNIDO), Industrial Statistics Database, 2001.

UNU/WIDER-UNDP World Income Inequality Database, www.wider.unu.edu/wiid/wiid.htm, 2000.

World Bank, (2002) Inequality and Globalization Judging the Data. A comparison of the UTIP data set on world pay inequalities with the Deininger-Squire data set. Mimeo.

World Bank (2005a) World Development Indicators (WB-WDI).

World Bank (2005b) World Development Report 2006: Development and the Next Generation (Washington, DC: The World Bank).

World Bank (2006) World Development Report 2007: Equity and Development (Washington, DC: The World Bank). 